\section{SEPNZ warm UP BJSM tendinopathy, back pain and $O A$ : sorting the evidence}

\author{
Blair Jarratt (1)
}

While the waves of the global pandemic continue to pound the borders of $\mathrm{New}$ Zealand-we are one of the luckiest countries in the world to live a relatively 'normal life' with community eradication of the virus leaving this small drop in the Pacific Ocean the envy of many of countries. Our children know of only minimal 'lockdown' periods, so it is with the greatest sympathy that I write in this international journal to others that are still severely restricted. New Zealand has been able to come out of the lockdown with an explosion of sports, and we watch and wait for our international friends to have similar freedom and the dream of Olympic games again. The front cover of this BJSM was from the recent Redbull ignite rugby union sevens tournament played in the beachside town on Mount Maunganui. Eighth men and eight women's teams united together to find hidden sevens talent from New Zealand in a weekend competition which was a feast of athleticism, energy and colour.

Spectators strolled freely between the grassy embankment filled with strangers to Christmas in the park where children played soccer together and listened to live music, and families splayed on a large field eating food from caravan vendors, dancing together. Over the back of the ground, the West Indies A team trained for upcoming matches, and $200 \mathrm{~km}$ away in Hamiton the New Zealand Black Caps took on West Indies in the first International cricket test match of 2020/2021 summer in front of a crowd. It is the stuff of dreams for which we are so thankful.

\section{WHATS IN \#OURBJSM}

In this Sports and Exercise Physiotherapy New Zealand (SEPNZ) edition of BJSM, we again celebrate the exercise super polypill and take a deep dive into musculoskeletal clinicians' bane of the tendons.

SEPNZ, Physiotherapy New Zealand, Wellington, New Zealand

Correspondence to Blair Jarratt, Physiotherapy New Zealand, Wellington 6011, New Zealand; president@sepnz.org.nz

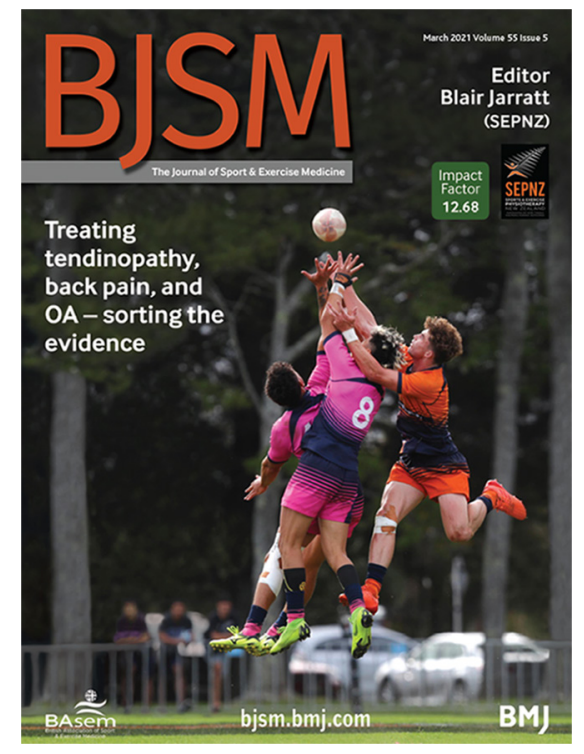

Professor Karim Khan provides an editorial on which specific modes of exercise training are most effective for treating low back pain which will be a topic that will always have clinician attention (see page 246). Dr Edward Roddy opens the lid on his research on optimising exercise and corticosteroid injection outcomes in patients with subacromial pain (impingement) syndrome, a factorial randomised trial (see page 262). Keeping with the exercise theme, Dr Alexandro Andrade provides an insightful infographic on exercise effects in patients with fibromyalgia (see page 279). In years to come, I am sure the benefits of exercise in the rehabilitation of COVID-19 infections will be well documented and fill this journal's pages.

For those of you reading this and not in a situation as fortunate as NZ, please don't take it as gloating. We want to paint the picture of what this world looks like out the other side of the year 2020 and 2021 and project optimistic thinking through pages of this edition of BJSM. The brain is a tool in recovery and has been studied in many musculoskeletal conditions. An editorial by Dr Sean Mc Auliffe Unimportant or undervalued? Psychological factors in tendinopathy-the review that wasn't! ties in flexing the grey matter as a rehabilitation component (see page 244). The editorial on Diagnosing Achilles tendinopathy is like good spaghetti carbonara - It's all about the ingredients, but not all chefs use the same recipe by Dr Robert-Jan de Vos focuses on the individualistic approach to tendon rehabilitation (see page 247). This issue is rounded out, keeping with the theme of tendinopathy by $\mathrm{Mr}$ Arco C. van der Vlist on which treatment is most effective for patients with Achilles tendinopathy? (see page 249).

We can't wait to stand together with our international friends and celebrate the reopening of the world with sport and activity. Let activity and unity of people be as symbiotic as the bacteria in the editorial by Dr Jon Lundberg (see page 243).

\section{WHAT'S HAPPENING WITH \#SEPNZ}

While our year has been relatively damped compared with other years, we have still managed to put out several courses, and our members continued to get there bimonthly SEPNZ bulletins. A milestone for 2020 was having two New Zealanders members complete our 'Sports Physiotherapy Certificate'this has been 5 years in the making to develop the individual courses and run these successfully throughout NZ. Those of you involved in organising CPD would appreciate this feat. We were lucky enough to sit down face to face as an executive recently and excitably chat about the proposed SEPNZ symposium for late in 2021-this will be a mix of virtual and live presentations and workshops. Let the work begin!

What the future holds we all don't know-:

'People say you don't know what you've got until it's gone. Truth is, you knew what you had, you just never thought you'd lose it.' - Clarissa Wild, Author.

Never is a time more accurate for this quote, but I can guarantee that sports and exercises will be part of the international language that gets us all back together.

Haere ra 2020, nau mai 2021

https://maoridictionary.co.nz

Funding The authors have not declared a specific grant for this research from any funding agency in the public, commercial or not-for-profit sectors.

Competing interests None declared.

Patient consent for publication Not required.

Provenance and peer review Commissioned; internally peer reviewed. 


\section{Warm up}

(c) Author(s) (or their employer(s)) 2021. No commercial re-use. See rights and permissions. Published by BMJ.

A) Check for updates
To cite Jarratt B. Br J Sports Med 2021;55:241-242.

Accepted 3 February 2021

Br J Sports Med 2021;55:241-242. doi:10.1136/bjsports-2020-103851

\section{ORCID iD}

Blair Jarratt http://orcid.org/0000-0002-1951-4453

$\underline{\underline{m}}$

$c$

응

के

$\stackrel{\frac{1}{8}}{2}$

$\overrightarrow{\vec{F}}$

듬

$\frac{\bar{\sigma}}{\bar{\sigma}}$

ڤ్ల

$\vec{\circ}$

$\overrightarrow{1}$

ज़ 